\title{
リン系難燃剤がリチウムイオン電池用電解液燃焼の消炎現象に及ぼす影響の評価 Influence of Organophosphorus Compounds addition on Combustion and Extinction Phenomena of Li-ion Batteries Electrolyte
}

\author{
O学 長谷 航 1 (北大工学院) 稲月 仁哉 ${ }^{2}$ (北大工学院) 西村 勝憲 2 (日立製作所) 正 藤田 修 1 (北大工学研究院) \\ Wataru Hase, Masaya Inatsuki, Katsunori Nishimura and Osamu Fujita \\ 1, Hokkaido University, Nishi 8 Kita 13, Kita-ku, Sapporo 060-8628 \\ 2, Hitachi, Ltd., 7-1-1 Omika, Hitachi, Ibaraki 319-1292
}

Ethyl Methyl Carbonate (EMC) which has been used in Li Ion Battery (LIB) is known as a flammable material. As a basis for fire safety improvement of LIB, the effect of Organophosphorus Compound (OPC) addition to EMC has been determined. The result showed that extinction limit increased with increase in OPC addition, while the effect of OPC addition tends to saturate with increase in the amount of $\mathrm{OPC}$ addition. It was also found that addition of OPC caused increase in flame temperature and fuel consumption rate (FCR). However, when $\mathrm{O} 2$ concentration comes close to the extinction limit, the rate of temperature decrease to the $\mathrm{O} 2$ concentration decrease is large and resulting decrease in FCR with decrease in $\mathrm{O} 2$ concentration becomes larger with OPC than the case without OPC. This trend causes the higher limiting oxygen concentration with addition of OPC to EMC.

Key Words: Lithium-ion batteries, Electrolyte, Organophosphorus, Extinction limit

\section{1. はじめに}

リチウムイオン二次電池 (LIB) は高いエネルギー密度, 優れた入出力特性などの性質から様々な分野での応用が期 待されている.一方でLIB は可燃性有機溶媒を電解液とし て使用するため, 火災安全性のさらなる向上が課題である. 電解液の燃焼抑制に対し, 難燃剤の添加が有効な手段之 して知られている．この中でもリン系難燃鼡（OPC）はフ ッ素系難燃剂と比べ環境負荷が低く安全であることから有 力な燃焼抑制剤として知られている. しかし，難燃剂添加 は電池特性（起電力，寿命等）に負の影響を与えるため,

(1) 電池性能を維持しつつ安全な LIB を実現するためには 難燃剂の添加量に対する燃焼特性，特に火災安全性に対す る指標となる消炎特性は重要な情報となる。

過去に行われてきた OPC 添加影響に関寸る研究俚電池性 能に注目したもの (2) や OPC を添加した時の水素やメタン の素反忘機满の推測 ${ }^{3}$ 4) 4 )にとどまり，難燃剂添加量と電 解液燃焼の消炎特性に注目した例は!ととんど見られない.

昨年度の稲月らの発表(の゙゙は, LIB の電解液の一種である 炭酸エチルメチル（EMC）を燃焼対象とし，OPCの一つで あるリン酸トリメチル（TMP）を添加した際の消炎限界酸 类濃度（LOC）変化を報告したが，本報告では TMP 添加 の有無に上る消炎近傍条件での燃料消費量減少挙動の違い を测定し，この結果に基づいて TMP 添加が消炎に及沓す 影響を考察した。

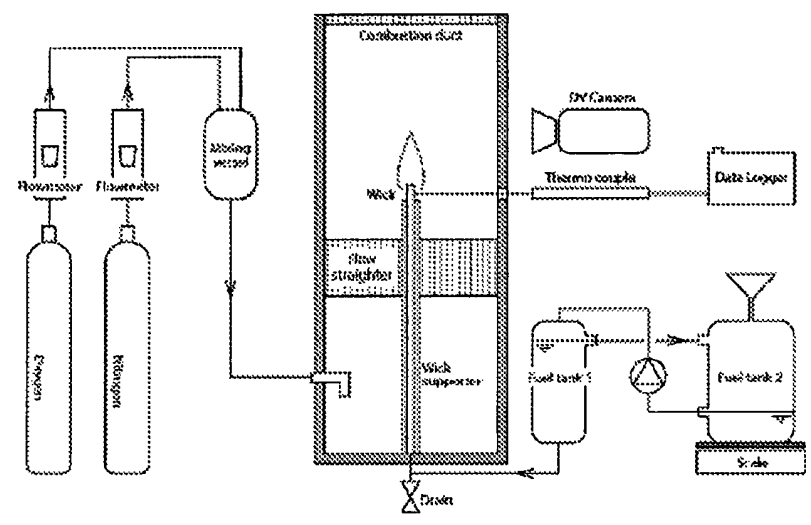

Fig.l Schematic experimental setup

\section{2. 实験装置および実験方法}

本研究で使用した実験装置の概略を図 1 亿示す. 本研究 ではEMCおよびEMC+TMPの消炎特性を灯芯燃焼で評価 することとした．灯芯火炎周困に流れる同軸空気流は窒素 と酸素の混合気であり，混合気中の酸素濃度および周团流 速 $(0.1 \mathrm{~m} / \mathrm{s}, 0.14 \mathrm{~m} / \mathrm{s})$ を任意に変化させた. 灯芯直径，灯 芯支持管以径及び燃焼筒以径はそれぞれ $4 \mathrm{~mm}, 6 \mathrm{~mm}$ 及び $80 \mathrm{~mm}$ とした. 灯芯引き山し高さは $7 \mathrm{~mm}$ とし, $\pm 0.5 \mathrm{~mm}$ の 誤差を許容した．定常な火炎を維持するため，燃料供給機 構には燃科の液面位置を一定にすることが可能なオーバー フロー方式 (5) を採用した. LOC, 火炎画像, 灯芯表面温 度，燃料消費速度を測定により観察した。なお測定にあた り輻射補正は行っていない，火炎の撮影は DV カメラによ る直接撮影を行った．燃料消費速度は燃料供給機構に設け た電子秤を用いた。

\section{3. 英験結果}

図 2 に EMC のみの LOCに対して EMCに TMPを添加し た場合の LOC の変化量を示す.ブロットは複数回行った実 験の測定平均值を，エラーバーは95\%信頼区閒を示してい る。なお，図中の破線注各実験結果の比較を容易にする目 的で描かれたもので，物理的意味仕ない．TMP無添加時と 添加時の LOC を比較すると, 添加量に対する消炎限界変化 率は，少量添加条件ほど大きいが，添加量の增加上ともに その変化率は小さくなることが分かった．また，LOCの添 加量に対する変化は周囲沋速条件によらず，同じ傾向を持 つことが分かった。

図 3 に TMP 添加時および無添加時の，酸素漂度 $20 \%$ お よび LOC + $1.5 \%$ の酸素濃度条件における燃料消費速度 （FCR）を示す．単位時間にお污る燃料の消費量 $[\mathrm{g} / \mathrm{min}]$ を FCR の単位と定義し, 10 秒毎に測定した燃料の質量変化少 ら近似直線を引くことで算山した．FCR は TMP 添加洔の 高酸素濃度側が最も高いが，酸素濃度を低下させると FCR は急激に低下寸る。一力 TMP 無添加時には FCR は酸素濃 度を低下させるほど FCR は低下寸るものの, TMP 添加条 件と比べるとその减少率任低い結果となった。 


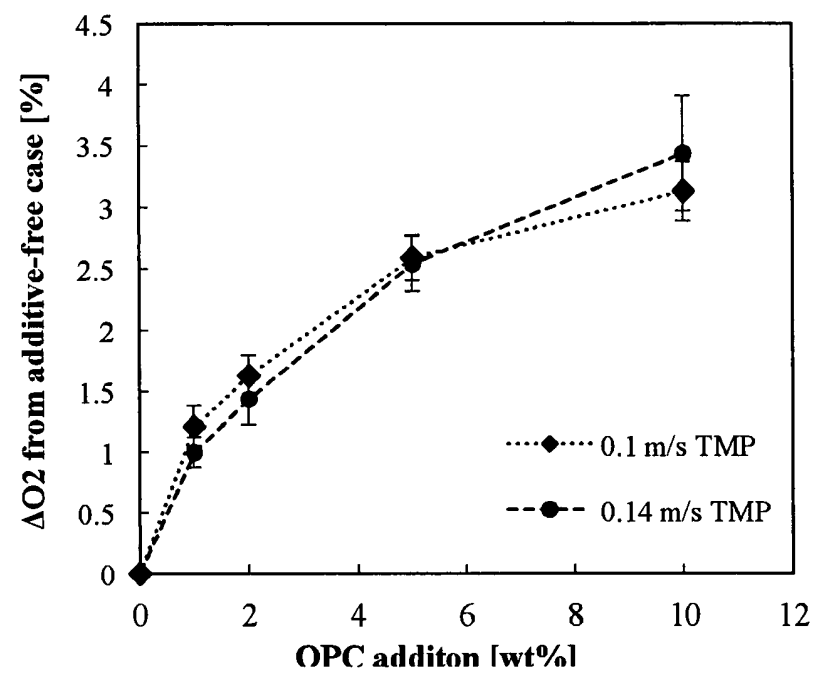

Fig.2 Change of limiting oxygen concentration by adding TMP

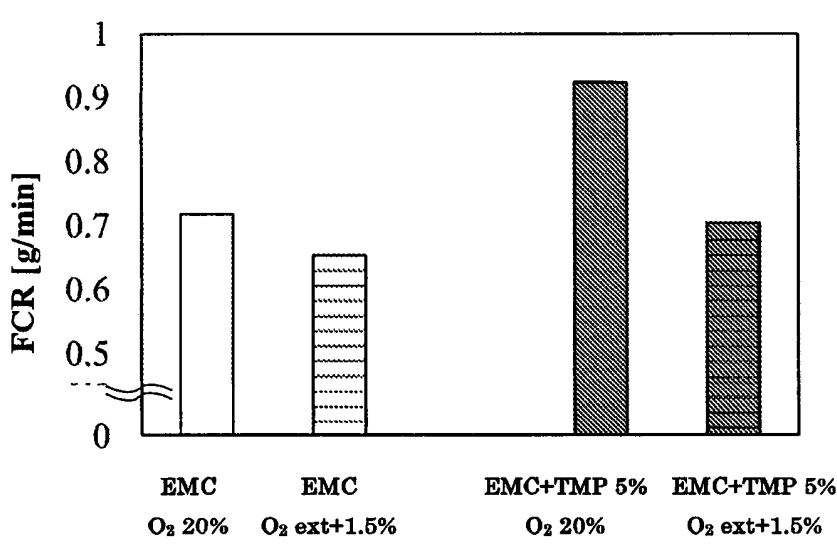

Fig3 Fuel Consumption Rate (FCR)

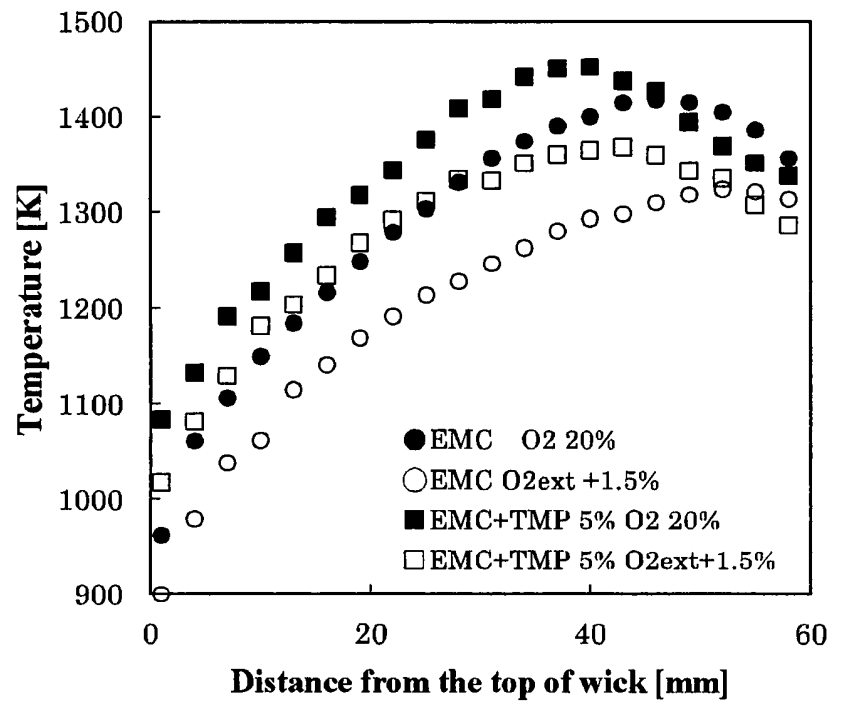

Fig.4 Temperature distribution at the center of flame

\section{4. 考察}

4.1 火炎温度上昗

図 4 に示されるような昨年度の稲月らの発表の結果 ${ }^{(6)}$ か ら，TMP 添加によって，高酸素濃度条件むよび消炎限界 近傍においても火炎温度は TMP 無添加条件より高くなる ことが分かっている．また，酸素濃度を低下させることで 火炎温度は TMP 無添加時, 添加時いずれの条件において も，酸素濃度 $20 \%$ の場合上消炎近傍（消炎限界酸素濃度 $+1.5 \%$ ）を比較するとほぼ同程度の火炎温度低下が生じて いる．この温度変化を考えたとき，先の FCRのデータにお いて，TMP 添加の昜合消炎近傍で FCR 大幅に低下寸ると いう傾向は極めて興味深い結果である。この点について性, 次節で考察する。

\section{2 燃料消費速度と消炎限界到達の関保性}

前述した火炎温度の結果の通り，高酸素濃度条件から消 炎限界近傍に酸素濃度低下させた時，温度変化は EMC のみの条件, TMP 添加条件いずれにおいてもほぼ同じ程度 の温度低下が生じている。一方で図 3 に示される FCRにお いて，酸素濃度の低下に対する FCR の減少率は，TMP 無 添加条件では低く, TMP 添加条件では大きい.これは TMP を添加することで火炎から灯㤁门の熱のフィードバック量 の酸素濃度を変化させた時の変化量が大きく，火炎を維持 するために必要な最低限の揮発量に到撻しやすくなり，消 炎限界が上昇したと考えられる。

TMP 添加時の FCR の減少率が高い理由として, 酸素濃 度を下げることによる $\mathrm{EMC}$ の燃焼反応速度の低下に加え， ラジカル捕捉に起因寸る生成エンタルピーが酸素低下に伴 い減少し, 酸素濃度変化に対才るる火炎温度の変化率が EMC のみの条件に比べて大きくなることが考えられる。

また，高酸素濃度条件から消炎近傍における火炎温度の 低下はほぼ同じにも関わらず，TMP 添別時の条件の方が， FCR の減少率が大きい，これは酸素濃度を下げることによ る火炎形状の変化が各条件によって異なり，筫のフィード バック量が変化することなどが理由として推測される.

\section{5. まとめ}

灯芯燃焼を用いて LIBに含まれる可燃性有機溶媒の EMCにTMP 添加し，消炎限界を測定した。この結果か ら，TMP 無添加時と比べて添加時の消炎限界は高酸素濃度 側一変化した。しかし添加量の増加とともにその変化率は 小さくなることが分かった，また，TMPの添加により火炎 温度の上昇および燃料消費速度が増加することが分かった。 さらに TMP を添加すると酸素濃度低下に対する火炎温度 低下が大きくなり，その結果, 酸素濃度低下に対する EMC の消費率の低下が大きくなり，上り高い酸素濃度で消炎す る結果となっているものと考えられる。

\section{参考文献}

(1) Masashi, O. et al., ECS Transaction, 1 (24) 13-19 (2006)

(2) X. L. Yao et al., J. of Power Sources 144 (2005) 170-175

(3) D. A. Knyazkov et al., Comb. and Flame 151 (2007) 37-45

(4) O. P. Korobeinichev et al., Comb. and Flame 118 (1999) 727-732

(5) Saso, Y. et al., Fire Tech., 29 (1993) 22-33

(6)稲月ら, 熱工学カンファレンス講演論文集, 17-18 (2013) 